IJBPAS, July, 2021, 10(7): 2321-2334

ISSN: 2277-4998

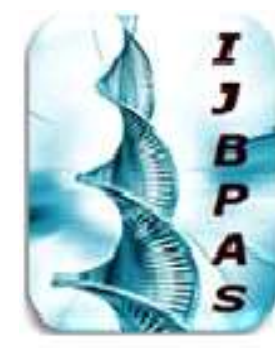

International Journal of Biology, Pharmacy

and Allied Seiences (IJBPAS)

'A Bridge Betusen Caboratory and Qqude'

WwW.ijbpas.com

ANALYTICAL METHODS OF SAXAGLIPTIN A DPP-4 INHIBITOR: A REVIEW

PATHAK S AND BANSAL $K^{*}$

Institute of Pharmaceutical Research (IPR), GLA University, NH-2, Mathura - Delhi Road, Mathura, Uttar Pradesh (India), Pin - 281406

*Corresponding Author: Keshav Bansal: E Mail: keshav.bansal@gla.ac.in; Mob: +91 9997592453

Received $18^{\text {th }}$ Aug. 2020; Revised $17^{\text {th }}$ Sept. 2020; Accepted $16^{\text {th }}$ Oct. 2020; Available online $1^{\text {st }}$ July 2021

https://doi.org/10.31032/IJBPAS/2021/10.7.5551

\begin{abstract}
Saxagliptin is dipeptidyl peptidase protein- 4 and active renal glucose reabsorption inhibitors. It is used in type 2 diabetes patients. They are administered as tablets. It has numerous analytical papers for Reverse Phase-High Performance Liquid Chromatography and Ultraviolet Spectroscopy estimation of the Active Pharmaceutical Ingredient or drug formulation. The use of chemical, drug and solvent separation methods used for green chemistry in pharmaceutical products is very difficult. Phosphate buffer and other toxic reagents were mainly used for estimation in this analysis and these agents damage tools as well as the environment and a lot of waste, so that novel analytical techniques for quantifying and identifying Saxagliptin should be developed for the person and the community as easily and safely as possible. This review focuses on the essential physicochemical state, properties, intervention, and aims to concentrate on various analytical methods for Saxagliptin estimation in pharmaceutical formulation.
\end{abstract}

Keywords: Saxagliptin, RP-HPLC methods, UV methods, Pharmacokinetic \title{
INTRODUCTION
}

Type 2 diabetes mellitus (T2DM) is a million people around the world and it is progressive, chronic condition. Absolute or relative insulin-characterized metabolic estimated that it will affect by 2030 , about disorder inadequacy. It is known that diabetes has a prevalence of around 220 440 million. Of these, roughly 90 to 95 percent of there is cases of T2DM [1]. The predicted increase in diabetes prevalence is 
Due to improved treatment, primarily due to an extended life span Facilities and increase in diabetic risk factors, especially physical inactivity and obesity due to sedentary lifestyle [2]. In T2DM patients, pancreatic $\beta$ cell function is progressively degraded and reflected into long-term ineffective glycemic control [3].Glycemic regulation that has been poorly achieved contributes to microvascular and macro-vascular (retinopathy, nephropathy)

Complications (cardiovascular). These are liable not just for a person, the enormous burden of disease but also at the economic level, and at the social level. Inhibitors of DPP-4 are administered orally and tolerated well. Besides the Improving the work of $\beta$-cells, stimulating the secretion of insulin and these agents minimize appetite by inhibiting glucagon secretion, weight stabilization and/or weight loss promotion T2DM in patients. Glucosedependent because they are more effective in reducing the mechanism of action, postprandial hyperglycemia, especially early stage hyperglycemia, Disease while T2DM patients continue to work pancreatic $\beta$ cells. Guidelines AACE / ACE, released in DPP-4 inhibitors were recommended in late 2009 as an alternative for Used as first-line mono therapy (6.5 to 7.5 percent $\mathrm{HbA1C}$ ) and in combination therapy (7.6 to 9 percent HbA1C). Saxagliptin is the recently approved agent in this class by US FDA in July 2009 as an adjunct to diet and exercise to improve glycemic control in adults with T2DM [4-6]. The characteristics of Saxagliptin are shown in Table 1. The structure shown in Figure 1.

Table 1: Characteristic of Drug Saxagliptin

\begin{tabular}{|c|c|c|}
\hline S.no & Parameter & Specification \\
\hline 1. & IUPAC Name & $\begin{array}{c}(1 \mathrm{~S}, 3 \mathrm{~S}, 5 \mathrm{~S})-2-[(2 \mathrm{~S})-2-\text {-amino-2-(3-hydroxy-1-adamantyl) acetyl]-2- } \\
\text { azabicyclo [3.1.0] hexane-3-carbonitrile }\end{array}$ \\
\hline 2. & Molecular formula & $\mathrm{C}_{18} \mathrm{H}_{25} \mathrm{~N}_{3} \mathrm{O}_{2}$ \\
\hline 3. & CAS number & $361442-04-8$ \\
\hline 4. & Molecular weight & $315.4 \mathrm{~g} / \mathrm{mol}$ \\
\hline 5. & Solubility & Sparingly soluble (in water with $791.8 \mathrm{mg} / \mathrm{L}$ at $25^{\prime} \mathrm{C}$ ) \\
\hline 6. & Vapor Pressure & $4.19 \times 10-11 \mathrm{~mm} \mathrm{Hg}$ at $25^{\circ} \mathrm{C}$ \\
\hline 7. & Dissociation Constant & $\mathrm{pKa}=7.90$ \\
\hline 8. & Volume of distribution & $151 \mathrm{~L}$ \\
\hline 9. & Clearance & Renal Clearance (single 50mg dose with $14 \mathrm{~L} / \mathrm{h}$ ) \\
\hline 10. & Biological half life & 2.5 hours \\
\hline 11. & Pharmacotherapeutic class & Antidiabetic \\
\hline 12. & Appearance & $\begin{array}{l}\text { White to yellow or light brown being non-hygroscopic and crystalline } \\
\text { powder }\end{array}$ \\
\hline
\end{tabular}




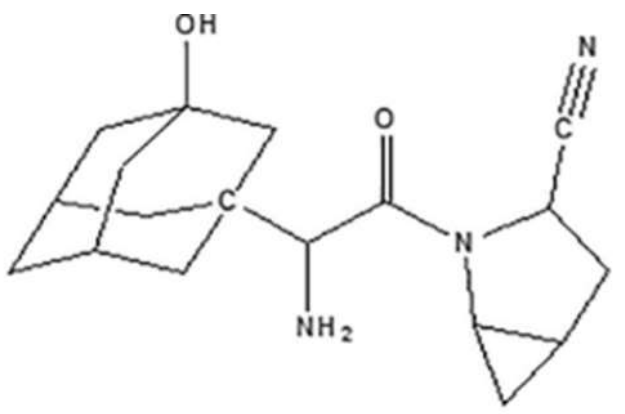

\section{Mechanism of Action}

Saxagliptin and its active metabolite M2 (two times less, respectively) Inhibitors of DPP-4 that are potent as parent drugs are by avoiding inactivation, the improvement of glycemic regulation

GLP-1 and glucose-dependent incretin hormones Polypeptide insulinotropic. This raises GLP-1 levels, Stimulates the secretion of insulin and decreases post-prandial the levels of glucagon and glucose. GLP-1's detailed behavior are Saxagliptin and M2 are more selective, as depicted in Table 2 . Inhibition of DPP-4 as opposed to DPP-8 (400- and 950-fold) Or DPP-9 enzymes (75and 160 -fold) or a wide panel of other enzymes ( $>4000$-fold) proteases [7]. It has been observed that inhibition of Alopecia produced by DPP-8/9, thrombocytopenia, splenomegaly, splenomegaly, multiorgan pathology, leading to death, and thrombocytopenia in mice, and in dogs for gastrointestinal toxicity [8].

Table 2: Action of (GLP-1) [9]

\begin{tabular}{|c|c|}
\hline Organ & Effect \\
\hline Heart & Increases cardiac output \\
\hline GIT & Delays gastric emptying \\
\hline Brain & Decreases appetite \\
\hline Liver & Decreases neoglucogenesis \\
\hline Muscle & Improves insulin sensitivity \\
\hline
\end{tabular}

\section{Pharmacokinetics}

Saxagliptin shows a bioavailability of $67 \%$ and is orally absorbed. Kidney and intestinal tissues shows its highest concentration and are distributed through the extra vascular tissues [10]. It shows both renal as well as hepatic excretion having a percentage excretion of $22 \%$ in feces and $75 \%$ through urine majorly [11]. Since the parent route of administration of the drug is found to be renal, its dosage should be proper in patients suffering from renal disorders. Being first order in kinetics, the mean plasma level termination of Saxagliptin shows a half-life of $3.1 \mathrm{~h} \mathrm{[12]}$. 


\section{Dosage and Administration}

In patients suffering from T2DM, the prescribed dosage is $2.5-5 \mathrm{mg}$ which is done orally regardless of meals [13].

\section{Analytical Methods of Saxagliptin}

\section{High Performance}

Liquid

\section{Chromatography Methods}

Daswadkar et al developed a method using acetonitrile and water at $\mathrm{pH}-3$ in a 20:80 ratio respectively with $1 \mathrm{~mL} / \mathrm{min}$ at $211 \mathrm{~nm}$ wavelength $^{14}$. Another method given by Scheeren et al using a $0.1 \%$ phosphoric acid at $\mathrm{pH}-3$ and methanol (70:30) with $1 \mathrm{~mL} / \mathrm{min}$ at $225 \mathrm{~nm}$ wavelength [15]. Zengad et al gave a new method using a methanol and water in $80: 20$ ratio at $0.8 \mathrm{~mL} / \mathrm{min}$ with detection at $212 \mathrm{~nm}$ [16]. Islam et al exhaust a novel method with using phosphate buffer and acetonitrile in 80:20 ratio and $\mathrm{pH}-2.7$ of buffer adjusted with ortho phosphoric acid at 210nm wavelength [17]. Recently Lokhande developed a latest method using methanol and phosphate buffer $(\mathrm{pH}-4.8)$ in a 70:30 ratio at $0.8 \mathrm{~mL} / \mathrm{min}$ with detection at $212 \mathrm{~nm}$ [18]. Tekkeli et al gave a method in human plasma with fluorescence detection using acetonitrile and $10 \mathrm{mM}$ ortho phosphoric acid at $1.3 \mathrm{~mL} / \mathrm{min}$ with detection of wavelength at $378 \mathrm{~nm}$ [19]. Above methods are for only Saxagliptin drugs after this method has been developed in combination also so there is two combination is very much important in analysis. One is Saxagliptin and metformin and another one is Saxagliptin and Dapagliflozin.

For Saxagliptin and metformin combination there are some method available out of these methods one is given by Hanan et al with using acetonitrile and phosphate buffer $(\mathrm{pH}$ 4.5) adjusted with ortho phosphoric acid 1.5 $\mathrm{mL} / \mathrm{min}$ with detection at 2220nm [20]. Another study done by Nyola for the same combination with using $0.02 \mathrm{M}$ potassium dihydrogen phosphate, acetonitrile and methanol in a ration of $(50: 25: 25) \mathrm{pH}-4.3$ at $1 \mathrm{~mL} / \mathrm{min}$ at $240 \mathrm{~nm}$ wavelength [21. Barge et al gave a new method for this combination with using methanol: phosphate buffer ( $\mathrm{pH}-$ 5) in a ratio of $1 \mathrm{~mL} / \mathrm{min}$ at $228 \mathrm{~nm}$ wavelength [22]. Caglor et al produce a sensitive method using a methanol and $50 \mathrm{mM}$ phosphate buffer $(\mathrm{pH}-2.7)$ at $1 \mathrm{~mL} / \mathrm{min}$ at wavelength of $225 \mathrm{~nm}$ [23]. Bangaruthalli et al develed a robust method with using Acetate buffer and acetonitrile and methanol (70:20:10) at 225nm with flow rate $1 \mathrm{~mL} / \mathrm{min}$ [24]. Recently Gurav et al gave a specific method using ammonium dihydrogen phosphate at $\mathrm{pH}-2.5$ and methanol (70:30) at $210 \mathrm{~nm}$ with $1.8 \mathrm{~mL} / \mathrm{min}$ flow rate for the same combination[25]. 
Another combination that is Saxagliptin and Dapagliflozin have a number of papers. One study done by Kommineni et al. gave a novel stability method in combination of Saxagliptin and Dapagliflozin with phosphate buffer (50) and Acetonitrile (50) maintaining $\mathrm{pH} 4$ at 225nm [26]. Patel et al. produce an easy, fast, exact, rugged and robust stability method in combination of Saxagliptin hydrochloride and Dapagliflozin using Potassium dihydrogren phosphate Buffer (45): Acetonitrile (55) at $220 \mathrm{~nm}$ with maintain pH 6 [27]. Singh et al. presented an easy and novel stability method for the combination of Dapagliflozin and Saxagliptin with buffer (53) and acetonitrile (47) at $230 \mathrm{~nm}$ [28]. Aswini et al gave a method using methanol and potassium dihydrogen phosphate buffer (45:55) at $210 \mathrm{~nm}$ with $1 \mathrm{~mL} / \mathrm{min}$ flow rate [29]. Another study done by padmaja et al using potassium dihydrogen phosphate and acetonitrile (55:45) pH-3.8 adjusted with dilute orthophosphoric acid at $210 \mathrm{~nm}$ with 1 $\mathrm{mL} / \mathrm{min}$ flow [30]. Suthar et al developed a new method with $0.05 \mathrm{M}$ Potassium dihydrogen phosphate $\mathrm{pH}-6.0$ and Acetonitrile (70:30) at $275 \mathrm{~nm}$ with $1 \mathrm{~mL} / \mathrm{min}$ flow rate [31]. Swamy et al gave a specific method using same mobile phase but the ratio is different that is $(45: 55)$ at $247 \mathrm{~nm}$ with $1 \mathrm{~mL} / \mathrm{min}$ flow rate [32]. Patel et al using potassium dihydrogen phosphate and methanol (85:15) at $222 \mathrm{~nm}$ with $1 \mathrm{~mL} / \mathrm{min}$ flow [33]. Patel et al using potassium dihydrogen phosphate (pH-6.0) and methanol (70:30) at $275 \mathrm{~nm}$ with $1 \mathrm{~mL} / \mathrm{min}$ flow [34].

Kadam et al gave simple method of methanol and water $(75: 25)$ at $270 \mathrm{~nm}$ with flow rate $0.9 \mathrm{~mL} / \mathrm{min}$ [35]. Usman et al gave simple method of methanol and ortho phosphoric acid $0.1 \%(60: 40)$ at $270 \mathrm{~nm}$ with flow rate $0.9 \mathrm{~mL} / \mathrm{min}$ [36]. Deepan et al gave a method using acetonitrile and water $(60: 40)$ at $248 \mathrm{~nm}$ with flow $1 \mathrm{~mL} / \mathrm{min}$ [37]. Gundala gave a robust method with using acetonitrile and orthophosphoric acid $(0.1 \%)$ in a ratio of 50:50 [38]. Phani et al use a buffer of ammonium dehydrogen phosphate and methanol $(65: 35)$ at $280 \mathrm{~nm}$ with flow rate $1.5 \mathrm{~mL} / \mathrm{min}$ [39]. Rao gave a new method using $10 \mathrm{mM}$ phosphate buffer $\mathrm{pH}-6.8$ and acetonitrile (40:60) at $260 \mathrm{~nm}$ with $1 \mathrm{~mL} / \mathrm{min}$ flow rate [40]. Donepudi et al gave a method in human plasma using $0.1 \%$ ortho phosphoric acidand acetonitrile in a ratio of 50:50 at $1 \mathrm{~mL} / \mathrm{min}$ [41]. All of above methods are shown in Table 3.

Spectrophotometric methods of Saxagliptin

Kalaichelvi et al gave a simple method at $208 \mathrm{~nm}$ in methanol [42]. Koli et al gave a 
method at $212 \mathrm{~nm}$ with using acetonitrile as solvent [43]. Recently Deshpandey produce a two different method of UV. Method A used at $211 \mathrm{~nm}$ and method B used at $204 \mathrm{~nm}$ in methanol [44]. For combination Saxagliptin and metformin Cholke and Nyola et al developed a method at $274 \mathrm{~nm}$ and $231 \mathrm{vnm}$ respectively in distilled water $[\mathbf{4 5}, \mathbf{4 6}]$. Method for another combination that is Saxagliptin and Dapagliflozin developed at 212 and $223 \mathrm{~nm}$ in distilled water [47]. All of above methods are shown in Table 4.

High Performance thin layer Chromatography methods of Saxagliptin

For Saxagliptin drug srividya et al produce a method using stationary phase silica gel aluminium plate $60 \mathrm{~F}_{234}(10 \mathrm{X} 10)$ and mobile phase is methanol: Chloroform $(6: 4) \mathrm{v} / \mathrm{v}$ at
$222 \mathrm{~nm}$ [48]. Rode et al gave a different method using stationary phase silica gel aluminium plate 60 F234 (10X10) and mobile phase is $1 \%$ methanolic ammonium acetate: Toluene $(5: 5) \mathrm{v} / \mathrm{v}$ at $215 \mathrm{~nm}$ [49]. Ghode et al produce a method using same stationary phase as above and mobile phase is Toluene:methanol:Ammonia $(6: 4: 0.2)$ at 222nm [50]. All of above methods are shown in Table 5.

\section{Liquid chromatography- Mass} Spectrometry method for Saxagliptin

Ghany et al developed a method using mobile phase potassium dihydrogen phosphate (pH-4.6): Acetonitrile: Methanol (40:30:30) at $208 \mathrm{~nm}$ [51]. All of above methods are shown in Table 6.

Table 3: Summary of HPLC methods of Saxagliptin

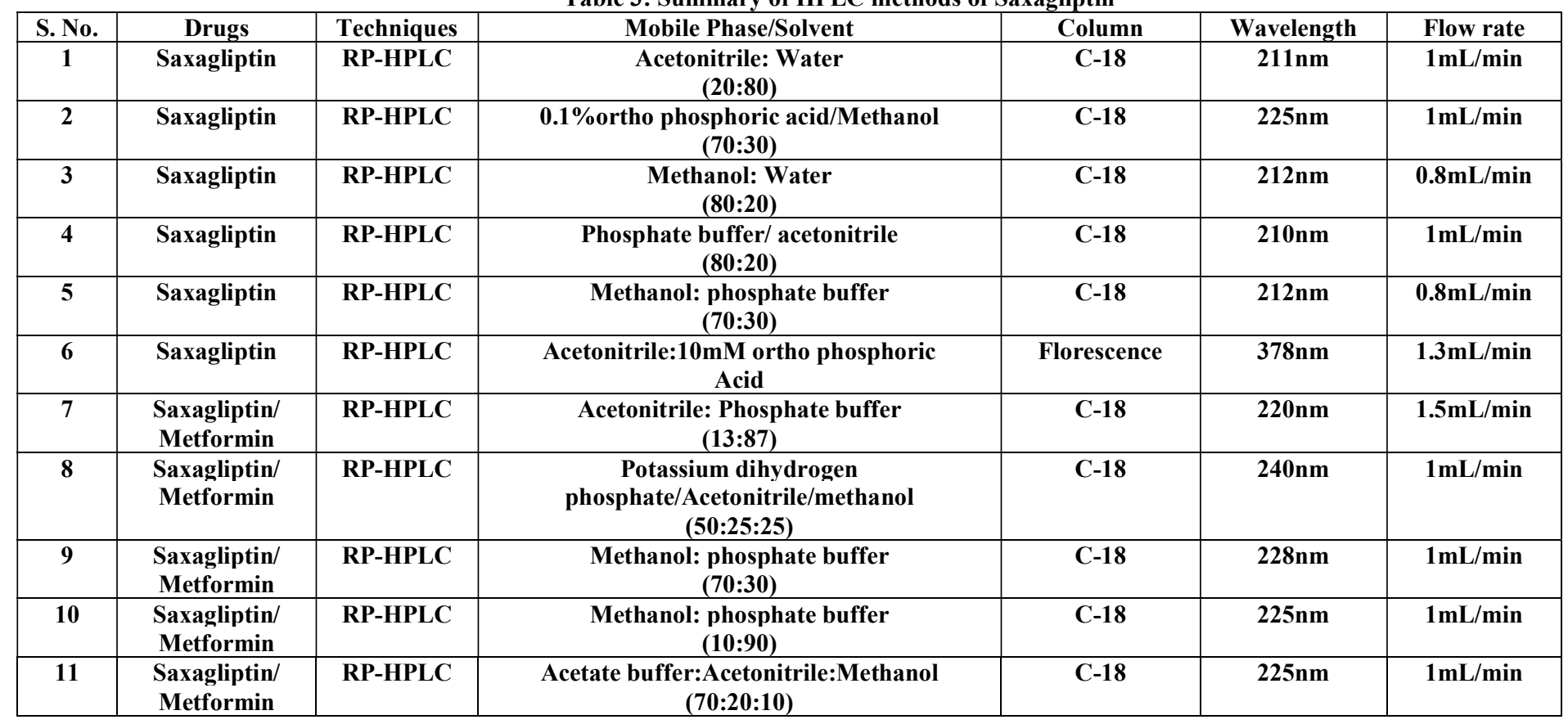




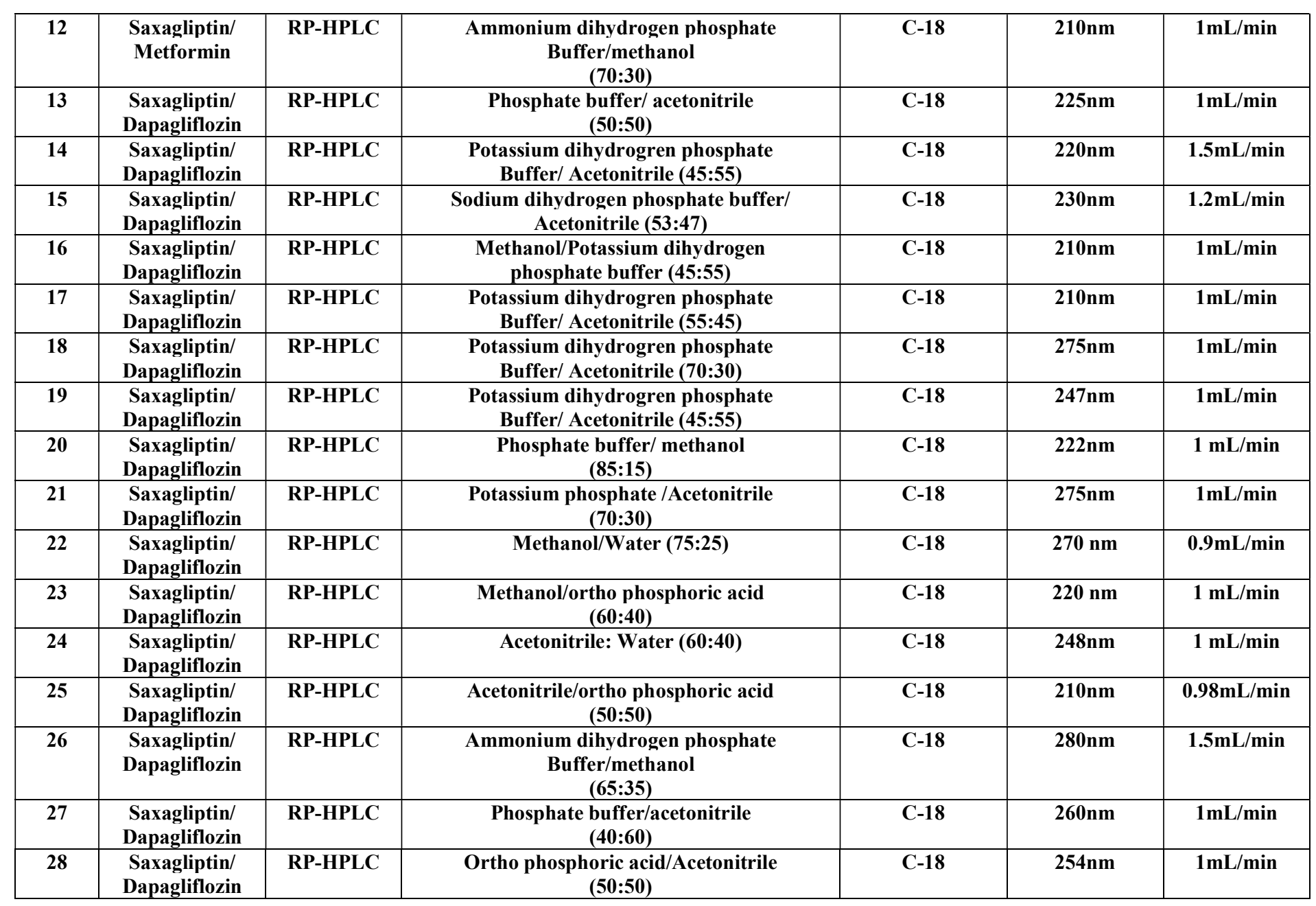

Table 4: Summary of Spectrophotometric Methods of Saxagliptin

\begin{tabular}{|c|c|c|c|c|c|}
\hline S. No. & Drugs & Techniques & Solvent & wavelength & Spectrophotometer \\
\hline 1 & Saxagliptin & UV-Visble & Methanol & $\mathbf{2 0 8 n m}$ & Double Beam \\
\hline 2 & Saxagliptin & UV-Visble & Acetonitrile & $\mathbf{2 1 2 n m}$ & Double Beam \\
\hline 3 & Saxagliptin & UV-Visble & Methanol & $\mathbf{2 1 1 n m}$ & Double Beam \\
\hline 4 & Saxagliptin/Metformin & UV-Visble & Distilled Water & $\mathbf{2 7 4 n m / 2 3 1 n m}$ & Double Beam \\
\hline 5 & Saxagliptin/Metformin & UV-Visble & Distilled Water & $\mathbf{2 7 4 n m / 2 3 1 n m}$ & Double Beam \\
\hline 6 & Saxagliptin/Dapagliflozin & UV-Visble & Distilled Water & $\mathbf{2 2 3 n m / 2 1 2 n m}$ & Double Beam \\
\hline
\end{tabular}

Table 5: Summary of HPTLC Methods of Saxagliptin

\begin{tabular}{|c|c|c|c|c|c|}
\hline S. No. & Drugs & Techniques & Stationary Phase & Mobile Phase & Wavelength \\
\hline 1 & Saxagliptin & HPTLC & $\begin{array}{c}\text { Silica gel aluminium plate 60 F } \text { F }_{254} \\
(\mathbf{1 0 X 1 0 )}\end{array}$ & $\begin{array}{c}\text { Methanol:Chloroform } \\
(6: 4)\end{array}$ & $\begin{array}{c}222 \mathrm{~nm} \\
\mathbf{2}\end{array}$ \\
\hline 2 & Saxagliptin & HPTLC & $\begin{array}{c}\text { Silica gel aluminium plate 60 } \\
\text { F254 (10X10) }\end{array}$ & $\begin{array}{c}\text { 1\%Methanolic ammonium } \\
\text { acetate:Toluene (5:5) }\end{array}$ & $\begin{array}{c}\text { 215nm } \\
\text { Ammonia (6:4:0.2) }\end{array}$ \\
\hline 3 & Saxagliptin & HPTLC & $\begin{array}{c}\text { Silica gel aluminium plate 60 } \\
\text { F254 (10X10) }\end{array}$ & $\begin{array}{c}\text { Toluene:Methanol: } \\
\text { Amm }\end{array}$ \\
\hline
\end{tabular}

Table 6: Summary of LC/MS Method of Saxagliptin

\begin{tabular}{|c|c|c|c|c|c|}
\hline S. No. & Drug & Technique & Mobile phase & Wevelenoth & Flow rate \\
\hline 1 & Saxagliptin & LC/MS & $\begin{array}{c}\text { Potassium dihydrogen } \\
\text { phosphate/acetonitrile/methanol } \\
(40: 30: 30)\end{array}$ & 208nm & $1 \mathrm{~mL} / \mathrm{min}$ \\
\hline
\end{tabular}




\section{CONCLUSION:}

Saxagliptin, (DPP-4) inhibitor used in diabetes has many HPLC and Spectrophotometric methods as individually as well as in combination those mentioned in Table 3-6. Dihydrogen phosphate buffer and other reagents mostly used in analysis that applicable to industries. These novel analytical techniques are used for quantify and defining Saxagliptin and that is safe for the chemist analyst and the community. There is much need of defining the impurities using LC/MS. Ultra performance liquid chromatography method not develop till now. So there must me develop method for the same.

\section{REFERENCES}

[1] Kulasa K, Edelman S. Saxagliptin: The evidence for its place in the treatment of type 2 diabetes mellitus. Core Evid 2010; 5: 23-37.

[2] Edelman SV, Henry RR. Diagnosis and Management of Type 2 Diabetes. West Islip, NY: Professional Communications, Inc; 2007.

[3] Dhillon S, Weber J. Saxagliptin. Drugs 2009; 69: 2103-14.

[4] Rodbard HW, Jellinger PS, Davidson JA, Einhorn D, Garber AJ, Grunberger G, et al. Statement by an American Association of Clinical
Endocrinologists/American College of Endocrinology consensus panel on type 2 diabetes mellitus: An algorithm for glycemic control. Endocr Pract 2009; 15: 541-59.

[5] Freeman JS. Role of the incretin pathway in the pathogenesis of type 2 diabetes mellitus. Cleve Clin J Med 2009; 76 Suppl 5: S12-9.

[6] Hollander PA, Kushner P. Type 2 diabetes comorbidities and treatment challenges: Rationale for DPP-4 inhibitors. Postgrad Med 2010; 122: 71-80.

[7] Saxagliptin (Onglyza) for type 2 diabetes. Med Lett Drugs Ther 2009; 51: 85-6.

[8] Wang A, Dorso C, Kopcho L, Marcindeviciene J, Kirby MS. Implications of the prolonged dissociation rate of saxagliptin, a highly potent and selective DPP4 inhibitor, on plasma DPP measurements [abstract no. 2088PO]. Diabetes 2008; 57 Suppl 1: A576-7.

[9] Drucker DJ. The biology of incretin hormones. Cell Metab 2006; 3: 15365.

[10] Drucker DJ. Dipeptidyl peptidase-4 inhibition and the treatment of type 
2 diabetes - Preclinical biology and mechanisms of action. Diabetes Care. 2007; 30: 1335-43.

[11] Hollander PA, Kushner P. Type 2 diabetes comorbidities and treatment challenges: Rationale for DPP-4 inhibitors. Postgrad Med. 2010; 122: 71-80.

[12] Dhillon S, Weber J. Saxagliptin. Drugs. 2009; 69: 2103-14.

[13] Fura A, Khanna A, Vyas V, Koplowitz B, Chang SY, Caporuscio $\mathrm{C}$, et al. Pharmacokinetics of the dipeptidyl peptidase 4 inhibitor saxagliptin in rats, dogs, and monkeys and clinical projections. Drug Metab Dispos. 2009; 37:1164-71.

[14] Daswadkar SC, Roy MA, Walode SG and Kumar CBM: Quality by Design Approach for the Development and Validation of Saxagliptin by RPHPLC with Application to Formulated Forms. Int J Pharm Sci Res 2016; 7(4): 1670-77.doi: 10.13040/IJPSR.09758232.7 (4). 1670-77.

[15] Scheeren LE, Marcolino AIP, Adams AIH, Rolim CMB (2015) Stability indicating RP-LC-PDA method for the quantitative analysis of saxagliptin in pharmaceutical dosage form BJPS 51(2): 461-466

[16] Zinjad SS, Patel SG, Gaikwad DD, Jadhav S L, Analytical Method Development of Saxagliptin $\mathrm{HCl}$ by RP-HPLC, Journal of Drug Delivery and Therapeutics. 2019; 9(4): 274278

http://dx.doi.org/10.22270/jddt.v9i4. 3040

[17] Md. Saiful Islam, et al, (2016), Development and validation of RPHPLC method for determination of Saxagliptin $\mathrm{HCl}$ in bulk and tablet dosage form, World journal of pharmacy and pharmaceutical sciences, Volume 5, Issue 5, 107119.

[18] Lokhande P. Development and Validation of an HPLC Method for the Analysis of Saxagliptin in Bulk Powder. International Journal of Trend in Scientific Research and Development.2020; 4(2): 37-41.

[19] Tekkeli SEK, Kızıltaş MV, Dinçel D (2013) an HPLC Method for the Determination of Saxagliptin in Human Plasma with Fluorescence Detection. J Adv chem 5(3): 810818 
[20] Hanan A. Merey, et al, (2017), Chromatographic methods for the simultaneous determination of binary mixture of Saxagliptin $\mathrm{HCl}$ and metformin $\mathrm{HCl}$, Bulletin of faculty of pharmacy, Cairo university, 55 (2017) 311-317. 17.

[21] Nyola N, Jeyabalan GS. Simultaneous Estimation of Saxagliptin Hydrochloride and Metformin hydrochloride in Active Pharmaceutical Ingredient by RPHPLC. AJPRHC. 2012; 4(3): 70-77.

[22] Vijaya U. Barge et al. Development and validation of analytical method for simultaneous estimation of Saxagliptin and Metformin $\mathrm{HCl}$ by using RP-HPLC method. Int. Res. J. Pharm. 2018; 9(6): 142-146 http://dx.doi.org/10.7897/22308407.096106

[23] Caglar S. A Validated High Performance Liquid Chromatography Method for the Determination of Saxagliptin and Metformin in Bulk, a Stability Indicating Study. J Anal Bioanal Tech. 2014; S6: 1-5.

[24] Bangaruthalli J, Swathi T, Kusumapriya N, N Hemalatha U, Sailaja KumariR. Method
Development and Validation for

Simultaneous Determination of Metformin and Saxagliptin by RPHPLC. International Journal of Scientific Development and Research. 2019; 4(1): 108-113.

[25] Gurav SB, Bhatia NM. Development and Validation of Novel Stability-Indicating LC Method for the Determination of Saxagliptin and Metformin. Indian J of Pharmaceutical Education and Research. 2020; 54(2s): s350-s357.

[26] Kommineni V, Chowdary KPR, Prasad SVUM. Development of a New Stability Indicating RP-HPLC Method for Simultaneous Estimation of Saxagliptin and Dapagliflozin and Its Validation as Per ICH Guidelines. Indo Americal Journal of Pharmaceutical sciences. 2017; 4 (9): 2920-2932.

[27] Patel AB, Pate DR, Shah Z. Development and Validation of Stability Indicating Method for the Simultaneous Estimation of Saxagliptin Hydrochloride and Dapagliflozin Using RP-HPLC Method in Tablet Dosage Form. World Journal of Pharmacy and 
Pharmaceutical Sciences. 2017; 6(10): 444-458.

[28] Singh N, Bansal P, Maithani M, Chauhana Y. Development and validation of a stability-indicating RP-HPLC method for simultaneous determination of dapagliflozin and saxagliptin in fixed-dose combination. New Journal of chemistry.2018; 42: 2459-2466.

[29] Aswini, R., Mukkanti Eswarudu M.and Srinivasa Babu. P. 2018. A Novel RP-HPLC Method for Simultaneous Estimation of Dapagliflozin and Saxagliptin in Bulk and Pharmaceutical Dosage Form. International Journal of Pharmaceutical Sciences and Research, 9(12), 5161-5167.

[30] Reddy Padmaja, B., Sivagami, B., Chandrasekar, R., Niranjan babu. M. 2018. A Highly Validated RP-HPLC Method Development for the Simultaneous Estimation of Dapagliflozin and Saxagliptin in Tablet Dosage Forms. International Journal of Pharmaceutical Sciences and Drug Research., 10(5), 372-378

[31] Asim M Suthar, Laxman M Prajapati, Amit K Joshi, Jimish R Patel, Mohammadali L Kharodiya.
2018. Estimation of Saxagliptin hydrochloride and Dapagliflozin propendiol monohydrate in combined dosage form. Journal of Innovations in Applied Pharmaceutical Science, 3 (2), 0107

[32] Gandla, Kumara Swamy, S. Shruthi, M. Rajkumar, D. Sudheer Kumar. 2017. A New Stabilty Indicating RP-HPLC Method for Simultaneous Determination of Saxagliptine and Dapagliflozin in Bulk and Combined Tablet Dosage Forms. Asian Journal of Pharmaceutical Analysis and Medicinal Chemistry 5(3), 113-121

[33] Patel PD., Pandya SS., Validated RP. 2018. HPLC Method for Simultaneous Estimation of Dapagliflozin and Saxagliptin Hydrochloride in Tablet Dosage Form. International Journal for Pharmaceutical Research Scholars, 7 (1), 9-15

[34] Patel SD, Patani P. Analytical Approach for Development and Validation of Stability Indicating Rp-Hplc Method for Simultaneous Estimation of Saxagliptin and Dapagliflozin in Pharmaceutical 
Dosage Form. Journal of Emerging

Technologies and Innovative Research. 2018; 5(12): 611-620.

[35] Kadam GM, Puyad AM, Kalyankar TM. RP-HPLC Method Development and Validation for the Estimation of Saxagliptin \& Dapagliflozin in Pharmaceutical Dosage Form. Journal of Emerging Technologies and Innovative Research. 2020; 7(3): 106-113.

[36] Usman MR, Ahmad S, Deore C, Shaikh T, Jain B, Imran M.Stability Indicating RP-HPLC Method for Determination of Saxagliptin and Dapagliflozin in Bulk and Tablet Dosage Forms. J. Pharm. Sci. \& Res. 2020; 12(4): 499-506.

[37] Deepan T, Dhanaraju MD. Stability indicating HPLC method for the simultaneous determination of Dapagliflozin and Saxagliptin in bulk and tablet dosage form. Curr. Issues Pharm. Med. Sci. 2018; 31(1): 39-43.

[38] Gundala A, Prasad KVSRG, Koganti B. Application of quality by design approach in RP-HPLC method development for simultaneous estimation of saxagliptin and dapagliflozin in tablet dosage form. Braz. J. Pharm. Sci. 2019; 55: e18129.

[39] Phani RSCH, Prasad KRS, Useni Reddy Mallu. A Study of New Method Development, Validation and Forced Degradation for Simultaneous Analysis of Dapagliflozin and Saxagliptin in Pharmaceutical Dosage Form by HPLC Method. Der Pharma Chemica. 2017; 9(20): 96-103.

[40] Rao PS, Chandran DR, Murali K, Srinivasu S. Stability indicating Isocratic Reverse phase HPLC Method with PDA detector for the Estimation of Saxagliptin in bulk drugs and in its Formulation. Int $\mathbf{J}$ Pharma Sci 2013; 3: 333-42

[41] Donepudi S, Achanta S. Simultaneous Estimation of Saxagliptin and Dapagliflozin in Human Plasma by Validated High Performance Liquid

Chromatography - Ultraviolet Method. Turk J Pharm Sci. 2019; 16(2): 227-233.

[42] Kalaichelvi, R. and Jayachandran, E. (2011) Validated Spectroscopic Method for estimation of Saxagliptin in Pure and from Tablet Formulation. International Journal 
of Pharmacy and Pharmaceutical Sciences, 3, 179-180.

[43] Koli SN, Belvotagi AV, Mudke RPK, Patil SA.UV Spectrophotometric Method Development and Validation for Estimation of Saxagliptin in API and in Pharmaceutical Dosage Form. 2019; 14(4): 166-179.

[44] Sanjeev V. Deshpande, Madhumita A. Roy, Shubhangi C. Daswadkar. Development and Validation of UV Spectrophotometric Method for Estimation of Saxagliptin in Bulk and Pharmaceutical Dosage Form. Int J. Pharm. Drug. Anal. 2016, 4(1), 30-34.

[45] Pravin Cholke1, Mrunal Shirsath, Yogita Temak, Aditee Kagde, Rutuja Lagad. 2018. Development and validation of UV-Visible spectroscopy method for simultaneous estimation of Saxagliptin hydrochloride and metformin hydrochloride in tablet dosage form. International Journal of Research in Pharmacy and Pharmaceutical Sciences, 3(4), 3134.

[46] Narendra Nyola, Govinda Samy Jeyabalan. 2012. Development and validation of uv-vis specctroscopy method for simultaneous estimation of saxagliptin hydrochloride and metformin hydrochloride in active pharmaceutical ingrident. J Pharm Educ Res., 3(2), 19-23.

[47] Zameeruddin M, Bundel SS , Bharkad VB, Khan HN, Thoke ST. Development and validation of UV spectroscopic method for simultaneou estimation of dapagliflozin and saxagliptin in synthetic mixture. Int. J. of Pharmacy and Analytical Research. 2019; 8(1): 59-66.

[48] Srividya, S., Swetha, E. and Veeresham, C. (2015) Development and Validation of a High Performance Thin Layer Chromatographic Method for Quantitative Analysis of Saxagliptin. American Journal of Analytical Chemistry, 6, 797-806. http://dx.doi.org/10.4236/ajac.2015. 610076

[49] Ghode PD, Baradkar SS, Sayare AS, Pachauri AD, Khandelwal KR. Stability Indicating HPTLC Method Development and Validation for the Estimation of Saxagliptin in Bulk 
and its Dosage Form. J. Pharm. Sci.

\& Res. 2019; 11(7): 2485-2489.

[50] Rode VP, Thorat SG, Tajne MR. A

Validated Stability-Indicating High

Performance Thin Layer

Chromatographic Method for the Analysis of Saxagliptin in Bulk

Drug and Tablet FormulationJ.

Chem. Pharm. Res. 2017; 9(5): 323-

328

[51] Abdel-ghany MF, Abdel-aziz O, Ayad MF, Tadros MM. StabilityIndicating Liquid Chromatographic Method for Determination of Saxagliptin and Structure Elucidation of the Major Degradation Products Using LC MS. J Chromatogr Sci. 2015; 53: 554-64. 